\title{
Renewal of the Language of Music Through Silence
}

\author{
Smirnova Tatyana \\ Ural Federal University, Ekaterinburg, Russia \\ TatianaVonNoble@yandex.ru
}

\begin{abstract}
The article analysis the possibilities of the language of music though silence. Considering music as a non-verbal communicative system, as a meaningful sign system as a part of semiotics, the author approaches the philosophy of structuralism viewing music as a text. Silence, as an artistic phenomenon, manifested itself brightly in music of the XX century when the understanding of art was reconsidered.
\end{abstract}

Keywords: Silence, music, communication, structuralism, Wittgenstain, V. Martynov, quietness

\section{Introduction}

The problematic of the article, which lies in the research of widening of the language of music through silence belongs to the sphere a of structuralistic approach to a music composition. It is necessary to distinguish quietness and silence, since for the study this difference is very important: quietness is an ontological, existential and natural phenomenon, and silence is an anthropological phenomenon associated with speech, which belongs to the world of people. Muteness belongs to the world which capable of speech.

Regarding the works of structuralism on text structure, we turn to music, as music, as it has been proved by Russian academics, is a system of non-verbal communication and as and as every cultural phenomenon can be viewed as a text. The article descusses the importance of the phenomenon of a written and published music composition - opus for European music, which enabled the composers of the XX century to implement an extra visual structure in the musical graphic notation and silence with the help of pausation.

Regarding the works of structuralism on text structure, we turn to music. Music is a system of non-verbal communication, as it has been proved by Russian academics, and as every cultural phenomenon can be viewed as a text. The article discusses the importance of the phenomenon of a written and published music composition - opus music in European tradition, which 
enabled the composers of the XX century to implement an extra visual structure in the musical graphic notation and silence with the help of pausation.

\section{Methods of research}

Musical pieces were analyzed for language structures under the paradigm of the structuralistic method. Through deconstruction, J. Derrida reduces language, cultural and political phenomena to a text and looks for the hidden sense, regarding the contradictions of the text as a characteristic of it existence.

Considering music as a sign system, which has pauses in its signs expressed through silence, the semiotic approach is applied.

\section{Research material}

The research is based on the philosophic works of such representatives of structuralism as F. Saussure, R. Bart, J. Derrida, J. Kristeva; the works of L. Wittgenstein; the works of such Russian philosophers and semioticians as A. Losev, M. Bahtin, P. Florensky, J. Lotman, V. Bibikhin. It is also on the musical pieces of the $\mathrm{XX}$ century composers - the representatives of the Second Viennese School (A. Berg, A. Schonberg, A. Webern) and such Russian composers as V. Martynov, A. Pyart, V. Silvestrov).

\section{Structuralistic studies of language}

Regarding a language like a structure, F. de Saussure analyzed language signs as its part, however a sign is not connected to the meaning, taking into account that the sequence of signs is random: 'speech ... is a system of signs in which the only essential thing is the union of meanings and sound-images' [Saussure, 1966, 15]. Saussure separated the language and the speech. In his opinion the language plays the leading role as it does not depend on the person and is a part of objective reality; speech takes the second place as it is an individual part in the speech activity, which stands for all verbal communication. The language is a social phenomenon; it is a public domain, unlike the speech, which together with speech activity is defined as an individual phenomenon.

Structuralism and post-structuralism are closely interconnected as they both are related to the structure. Structuralism looks for the language structure in texts and cultural phenomena while post-structuralism deals with ambivalence of structure. According to structuralism academics, the speech creates an indivisible stream while writing is filled with pauses (dots and commas). 
As a representative of post-constructivism, J. Derrida considered the language as a source of disorganization, which has no consistency. He reduces both language and cultural, social and political phenomena to a text, thus deconstructing the language. After deconstruction only a text is left. The sense of deconstruction is to decompose philosophical works and explain philosophical concepts. Deconstruction looks for implicit contents of the text, tries to explain the contradictions of the text as a characteristic of its existence. Comparing the speech and writing, Derrida unconventionally privileges writing over speech: 'no consciousness is possible without the voice. The voice is the being which is present to itself in the form of universality, as consciousness; the voice is consciousness' [Derrida, 1973, 79-80]. The speech pronounced by the voice is not considered as a system of signs, as the voice has no mediator unlike writing where this function is provided by a material medium. However, the insubstantiality of the voice is a misconception and Derrida wanted to show that the speech is writing since the voice serves like a medium.

For R. Bart language is the foundation and source for understanding all phenomena, as everything in social reality is based on language. As the sense appears only when the events are named, language providing communication bears social meaning and is considered to be the public domain unlike speech which is an individual phenomenon. He analyzed the interaction of individual and public phenomena, speech and language. Looking for the solution to this problem, he approached writing, which is a combination of the language codes and subconscious in speech: 'Writing is that neutral, composite, oblique space where our subject slips away, the negative where all identity is lost, starting with the very identity of the body writing' [Bart, 2002, 221]. Then and there the culture turns into a text. The language and the style are the main elements of writing: 'Now every Form is also a Value, which is why there is room, between a language and a style, for another formal reality: writing' [Bart, 1968, 13]. The style is the way in which the author expresses his thoughts.

J. Kristeva does not regard the text as a lingua franca as it does not represent reality but modifies it: 'as the partner of a subject is a text, thus the subject itself turns up in a text; it gave rise to the personal-impersonal poesy, which swept away a psychological subject, the descriptions of passion without a moral conclusion, phenomenon, incident' [Kristeva, 2004, 652]. The text does not only line up with reality, but modifies the grammar of the language, thus belonging to the language and to the society, and it creates new meanings. 


\subsection{Russian linguistic philosophy}

Linguistic philosophy, including such questions as the problem of expression of meaning, which is inexpressible through the verbal means of communication, the subjective nature of a thought, attracted the attention of both Western and Russian philosophers. Non-verbal language serves as the inner speech and silence limits the language. Non-verbal structures of the consciousness and the frames of the language, studies of a sign and sign systems, content and meaning were developed within the frames of semiotics. Thinking and the language, signified and denotative, the influence of non-verbal speech tools on meaning are examined in the works of such Russian academics as M. Bakhtin, P. Florensky and A. Losev.

Studying of the language is central to Losev's philosophy: a symbol expresses the essence being a part of the material world, and a symbol expressed by a word is added to the outer word. Thus, all the world is expressed in words, the world is equal to the word. Speaking about skeptics, Losev analyzes silence as something non-expressed, the summit of wisdom.

4.2 Silence as limitation of language in Wittgenstein's philosophy.

Wittgenstein defined the limits of the world through the limits of language [Wittgenstein, 1994]. Not only the consciousness, but all the cultural phenomena are determined only by language. However not everything can be expressed with the help of the language, it is especially true when we speak about art as the total of images, emotions, sourcing of new meanings where we can observe the limitations of the language. A solution can be found in the silence, it solves the problems of objects and predicates when the inexpressibleness of an object and a function has not any solution in language. 'What can be said at all can be said clearly; and whereof one cannot speak thereof one must be silent' [Wittgenstein, 2020]. The silence and the word do not eliminate each other, but exist simultaneously, limiting each other. The word must experience silence. 'Attitude deals with attitude, but in this case, ... a person contradicts himself. The only way out is to establish this fact in silence. This kind of silence can be called genuine, as it is not only the absence of sound, but also the inner silence, thus even our mind has to keep silent. [Loreti, 2016, 37-38]. The essence of the language varies in both early and late works of Wittgenstein. In his early works, the main function of language is information transfer and fixation of the facts of the world. In his late works (Blue book and Brown book) the language exists not for description, but for the expression of reality, it cannot be singular or united. In his later 
works, we can also face the concept of 'genuine silence". Turning to practice after studying theoretical problems is done in silence, like resolving challenges cannot be realized with the help of the words, but only through the inner silence: 'the idea of genuine silence lies in the idea that the theoretical response to the theoretical questions of philosophy is returning to practice'. According to Wittgenstein, this returning will be silent in the sense that people will not discuss the philosophic issues with the help of the words. Philosophical questions are resolved with the help of strict, genuine inner silence which in the framework of the late Wittgenstein ideas partially coincide with chaotic noisy language games [Loreti, 2016, 39]. The silence and speech share a common foundation, they originate in conversation, which enables both speaking and silence, thus developing silence as the follower of a conversation. The speech does not stop in silence, it continues in it.

\section{Music as a non-verbal mean of artistic communication}

The interaction between the author and the recipient through simple, non-voice signs in art serves as a kind of artistic non-verbal communication through the release of information with the help of the means of such communication such as intonation, gestures, mimics, etc. Visual artistic communication exists in painting, sculpture, architecture; acoustic communication exists in music, artistic communication at the theatre and some other genres of modern music is expressed via both acoustic and visual means.

Scientists distinguish numerous functions of music such as cathartic, esthetic, cognitive, conveying emotions, esthetic and others. The main function among them is definitely the communicative function: music is a non-verbal tool of communication and it is expressed in the interaction of the composer with the performers and listeners. Music's non-verbal tools of communication enable listeners and performers to enter the world of music, as it is non-verbal by its very nature. The non-verbal pre-logical character of music (Losev 'Music as a matter of logics') makes it comprehensible to any person no matter if he can speak the language of the country or the language of the country where the composer come from. Music has its own expressive means such as the beat, rhythm, motives, melody and so on. Common features, which unite the language of words and the language of music, are the sound and speech.

Perception ties the creative concept of the composer, its performance and listeners into the united music system. The music supposes the communication of the composer with the listeners and performers. Music com- 
munication is expressed in the same way as speech and unlike verbal speech which serves as an act of communication, music speech serves as a one-sided process from the composer, who produces this music speech, to the listener. 'Communication and interaction still not distinguished in linguistics and semiotics thus they do not make it possible to distinguish the language of communication and the language of message ... we deal with two different sign systems understanding of which is crucial for the third class of these systems — artistic languages [Kagan, 1988, 272].

In terms of hermeneutic language is united with reality. In the modern science interpretation is connected with the text. Music is analyzed as a sign language system and as a tool of artistic communication. Academics who consider music as music speech attach importance to it as a communication tool, since music serves as a speech activity — it includes breathing, which influences the structure of music, the construction of music expresses its contents as the speech does, but unlike speech it expresses the meaning not through the meaning of the words, but through the aural images which are generated by harmony, rhythm and intonation. Music serves as expression while speech serves as nomination: 'could a message, which does not consist of signs by which we primarily mean the words of a natural language, bear some meaning? ... Bearing in mind painting, music and cinema, we cannot help but agree' [Lotman, 1973, 382].

The music is more that simply sound phenomenon, it has contents, impossible to narrow down to a system of signs. However, in linguistics there is a theory which views music as a non-language and non-sign phenomenon because it is considered to be a system with non-meaningful units, thus it is impossible to decode its signs.

A creation is viewed as a unique sign as it is impossible to eliminate a part of a production without losing elements of the contents. In art, a sign is equal to a speech process, which exists in time and/or space. A literary text is viewed as an integrated whole. This is also the case of music, as only the whole piece can be considered as a sign while its separate elements are only parts which have no general idea. 'In artistic creation pronunciation of a sign is always a speech process which exists in time (oral culture, music), in space (plastic arts, architecture) or in both (stage arts). It is necessary to be aware of the elements of a sign-production, which composes it as artistic speech. In every-day (non-artistic) speech the main unit is a statements which consists of the words-signs ' [Bonfeld, 1996]. 
According to Yakupov, the language of music has a code which transfers the artistic information into materialized information. In other words, a performer decoding a music notation reconstructs the conception of the composer. However, the conception lies not only in music notation but also in non-music information. Music notation performs the main functions necessary to decode the concept: it includes a coded sign-message; it conveys emotions, attitude, succession and the assembly of musical instruments and so on.

The coded music notation and performed acoustic music differ. The former is a sign system which is not able to impress the listener and carry the audience to the emotional world of associations and artistic images. However, performed music possesses all these qualities: 'a composer is a 'writing person', it is a person who creates music texts which later turn into real music'. [Martynov, 2002]. However, it is not always the case that the music is written first and performed later, since before the XII century the music was composed to be performed, it was not necessary to write it. In music there are 'two opposite principles which make a foundation for music notation the diastimatic principle or the principle of accurate fixation of the intervals and the adiastimatic peinciple where the emphasis is not put on the fixation of the intervals but on the fixation of other parameters of melodism united by the idea of articulation. Interestingly, that articulation here is understood in the way it was regarded by Zemkovsky, as music of an oral tradition where we find out the intonation meaning through the behavior of a performer [Martynov, 2002]. Line notation was invented by Guido de Arezzo who managed to transform an early idea of line principle of music notation into our conventional system. One of the advantages of line notation is that it provides a graphic image of a music piece. The composer's design does not always lies solely in the audible music: 'very often a composer's structure cannot be heard by ear, but can be recognized by the eye; symphony by Vebers 21 is a shining example of this, when the audio perception truly cannot give the impression of that crystal complexity of structure which can be observed looking at the music's scope' [Martynov, 2002]. Music has an important visual part which can fully reveal the composer's design, and sometimes it happens that a piece is fully formed only in the process of notation.

According to Rappaport, the written language of music, as a graphic music notation, also serves as a sign system, which possesses its own functions, refers the performer to particular characteristics such as music instruments, sequences of sounds played, etc. It provides interaction be- 
tween the composer and the recipient through non-words, non-speech signs, from the viewpoint of semiotics; it is considered as an artistic non-verbal communication - transfer of information with the help of communicative means such as intonations, gestures, mimics, etc. Art possesses the kinds of non-verbal mediums, which are not present in everyday speech, such as music, choreography, painting.

The issue of sense in music is a problem of the perception of some kind of information, or message, which is communicated to the listeners. On this basis of communicative characteristics, in general, music can be regarded as a kind of speech (B. Asafiev, B. Teplov, L. Masel, etc.) In addition, a crucial role is played by intonation, which can be the main medium of music.

\subsection{Intonation and rhythm which generate silence in music}

Music construction passes on the contents like speech, but unlike it, music communicates spiritual meaning not through the words, but through the rhythmic and intonation images (B. Asafiev, M. Gudova, L. Zaks, V. Medushevsky). These images are created by the unity of rhythmic and pitch, which in turn creates harmony and intonation. Audile music provides sign and symbolic expression, while human speech serves to express inner intellectual and emotional-volitional processes and states of a person.

Intonation is one of the main aspects crucial for our investigation as a characteristic of a music piece and by itself. Music has rhythm and time and pitch aspects, which in turn consist of harmony and intonation. The rhythm provides timing in a music piece in particular and in text in general. The rhythm is based on the metric system and aims at the harmonization of time, a certain kind of rhythm. There can be observed certain lose of rhythm which deasl with verbal text (different kinds of metric design, rhythmic inversion when the stress does not match with a metric stress, arrhythmia, etc.) and music - multimeter, syncopated rhythm, etc. It is easier to observe rhythm errors in music rather than in speech.

Intonation expresses the unity of the non-semantic and semantic level of a composition. Intonation is closely connected with expression and music intonation has much larger value and turns into a musical language and thus a mean of communication. Intonation provides the content function of music.

In Russia, one of the problem of intonation was first studied by B. Asafiev, who paid attention to the fact that music intonation 'is comprehension of music speech which belongs to a particular social sphere [Asafiev, 1971, 355]. The essence of intonation is revealed in 'three interrelated forms of ex- 
pression: a composer's, a performer's way of thinking and the listeners' way of thinking while listening and perceiving music'. [Shishliannikova, 2013].

In addition, iIntonation defines the semantic message of a composition, turns the daily state of mind to artistic perception' [Gudova, 2004, 123].

As Asafiev states, intonation plays a much more important role in music rather than in any other art, as it is an intonation art by itself where the expression of intonation defines the sense of music. It is through the intonation as a non-verbal means of communication, that the listener perceives and comprehends music.

\subsection{Pre-conditions of silence in music}

The role of music notation in the modern world is closely connected with the change of status and context of art existence.

Martynov in his book "The zone of Opus Posth. The birth of a new reality" looks into the dynamic of "opus" music development (attached to the published work) and Opus posth-music, which represents a number of procedures and operations with non-fully used opportunities of opus-music. The transition to opus posth-music goes along with the changes in such notions as "a composition", "a text", "an author" and "a copy", "consumption" and "a publication".

Martynov divides music into opus music and opus-posth music. The word "opus" means work, labor, activity, making, creation, composing and thus, speaking about "opus-music" we must speak about music as a labor, occupation, making, creation or composing.

The term "opus-music" points at the essence of the western European composers' music and at the same time stresses the fact that it is set apart from any other music practices and traditions of the world. The word "opus" emerged in the composers' practice quite late, and it has been used only since the end of the XVI century.

Opus refers to a published work and a non-published work cannot be considered as a work of art. The act of publishing turns a potential work of art into a real work of art.

The need to stimulate music creation has appeared because it is impossible as such. Understanding of the decline in artistic expression and feelings lies behind the need of stimulus to create new music. This is not going to be opus music, but opus posth-music, as this music comes from understanding that opus music is dead. 'For example, "Quiet songs" by Valentin Selverstov can be considered as one of the early examples of opus posth-music which consists of a sequence of simulacrum, but they are a special kind of simu- 
lacrums, they are conscious and this awareness turns them into a genuine facts of art' [Martynov, 2005, 17-18]. The same kind of simulacra, which turn into the facts of post-art can be observed in the works of A. Pyart, A. Rabinovich, G. Pelitsis and others, 'music which can be qualified as opus posth-music and which makes you aware of the fact that the only last real topic for live genuine art can be only the death of opus-music, the death of art as such'. [Martynov, 2005, 18]. Opus posth-music contains a certain set of operations with not fully used opportunities of opus-music. This fact lies behind the secondariness of this kind of music.

The beginning of the transfer to opus posth-music coincides with changes of such issues as "a composition, 'a text', 'an author' and 'a copy', 'consumption' and 'publication' and their replacement with such notions as 'a behavior pattern', 'a project', 'a character author' and 'flickering' which imply a brand new view of art works.

In his book "The end of the composers' era" Martynov views the problems of composers in the present and in the past and tries to predict the perspectives of music development. Martynov believes that the time of the composers is gone; however, music is not going to disappear with them. At the same time, we can observe the withdrawal of performing art and its transfer to a separate important field of music realization. We can see a separate class of performers who are not necessarily composers but can reproduce music whitten by others using music notation. Simultaneously, there is a clearly defined need for individual reading of music through adaptation of music compositions written with music notation. A special emphasis is put on the individual style, the manner of performing and in general the idea of sound of different compositions.

\subsection{The structure of silence in music and philosophy}

Structuralists clearly differentiate the speech and the language; however, in this article I do not draw this line as silence refers to both language and speech, the latter originates in silence and plunges into it. Silence can be a sheer lack of words, however if it stands for words and it turns into a statement, in this case, it is more than lack of speech. Speech is not possible without silence; silence in forms of pauses creates borders of speech. Silence is opposed to a word.

Silence is an anthropological phenomenon, which belongs to the human realm. Based on the assumption that silence is accompanied by the inner speech we can come to a conclusion that silence expresses the inner world of a person. A person has a choice to speak or not to speak, to break silence or 
to keep it. In the works of Bibikhin "The language and philosophy" the choice to keep silence or break it lies in the fact that a silent statement is 'a word proved by the threshold of the silence. The word of the inexpressible.' [Bibikhin, 2002, 34] Silence and speech are opposed to each other, but generate each other. Bibikhin defines speech through silence: 'A text is made up of silence and the word. The fact that silence is the foundation of the language does not define the language yet, but makes it clear that the relation of a word to an object is not a mere description'. [Bibikhin, 2002, 30].

Silence serves as the soul of speech, sound and the language, it initiates the beginning of a conversation and manifests itself only when there is no conversation. Speech and silence are interrelated. However, there is the other side of silence and speaking as although silence serves as the foundation of speech, it cannot be considered as the foundation of the culture: 'The silence can be safely kept only by the word ... And both a person and culture are truly kept not by silence, but by the word proved by the threshold of silence. The word of inexpressible [Bibikhin, 2002, 34].

If we study silence as means of communication, the sign nature of the language is unfolded in different ways and different academics provide different classifications of silence: 'for J. Jensen it is the classification of the connection, interaction, recognition, judgment, action. For T. Bruno it is the psycholinguistic, socio-cultural interactive form of silence. V. Bogdanov defines three main functions of silence: role-marking, which implies the change of communication roles, informative and sintactico-constructive' [Katukhina, 2009, 91]. The sign nature of silence gives an opportunity to compare silence and the language which decreases the possibilities of silence in relation to the other spheres of application.

If in everyday life we interpret silence as emptiness and lacking in contents, in music it is filled with contents and has an absolutely different meaning. Many academics associate the unity of silence expressed in the pause and music with the sacred sphere: 'the sacred meaning of a pause in music is eventually traced to the metaphysical interpretation of music and musicality as the greatest spiritual force' [Sidneva, 2012, 31]; 'all the good things that a person can tell is no match for the language of the fundamental nature which is incomprehensible for us; this incomprehensibleness must silently manifest itself in the pause [Mikhailov, 1998, 127].

In the works of some composers music emerges into silence, others in turn create music in silence. 'Different composers with absolutely di- 
verse esthetic characteristics such as Vebern, Kancheli, Scriabin and Cage had the knack for filling the silence with spiritual meanings. Late preludes of A. Skriabin with their "disappearing" sound which vanishes into the silence, with graphic expression which displaces the notes with pauses reflect a subtle and complicated way of the sound dematerialization, and finding the pure, 'inexpressible' spirituality' [Sidneva, 2012, 31]. 'K. Stockhausen reflects on the silence: 'we have not mastered this skill yet in the previous forms of art - silence falling at a definite moment and in the silence which falls suddenly or gradually, experience the variety of silence in the same way as we experience sound' [Nekrasova, 2016, 191]. In other words, silence and silentness find their ways in the world of music.

\section{The results of the research}

A music composition serves as a system of signs every one of which is unique so it is not possible to eliminate any of them without losing a part of its contents. In the music art, a sign serves as a process, which manifests itself in time or in time and space. Music is full of meanings, which cannot be narrowed down only to a system of signs and the implicit means of the verbal language. Unlike a verbal language, which serves as an act of communication and which is impossible, if all the participants of the conversation do not share the same language, music speech serves as an open communication process from the composer, who generates this speech, to the listener. This kind of openness is a great communicative and consolidating advantage of music. It is an open communication system which can be entered by anybody regardless of his or her competence in the language of music.

Music and speech both serve as means of communication as they bear a message, information and content. Music communicates its contents through the whole of music images. As for the vocal music, this communication is expressed by the intonations.

From the XX century, we can observe the reinterpretation of the phenomenon of silence in the musical sphere. The world of music besides music, noises and other sounds, has begun to pay attention to silence and silentness, and regard them as a part of music.

\section{Acknowledgment(s)}

This research was financially supported by the Russian Foundation for Basic Research (Grant No. 17-29-09136\18 "Multilingualism in the Era of Post-literacy: 
Philosophical and Cultural Studies and Methodological and Pedagogical Development of a Multilingual Education Model").

\section{References}

1. F. Saussure. Course in General Linguistics. McGraw-Hill Book Company, New York (1966). ISBN: 978-0-01-016524-3

2. J. Derrida. Voice and Phenomenon: Introduction to the Problem of the Sign in Husserl's Phenomenology. David B. Allison Newton Garver Northwestern University Press Evanston (1973). ISBN 0-8101-0397-4

3. R. Barthes. The Death of the Author. Alistair McCleery \& David Finkelstein, New York: Routledge (2002).

4. R. Barthes. Writing Degree Zero. Hill and Wang, Inc., New York (1968). ISBN: 8070-1545-8

5. Yu. Kristeva. Izbrannyye trudy: Razrusheniye poetiki [Selected works: Destruction of poetics]. Moscow (2004). ISBN 5-8243-0500-5

6. L. Wittgenstein. Filosofskiye issledovaniya. Filosofskiye raboty. Ch. I. [Philosophic investigations]. Gnozis, Moscow (1994). pp. 75-319. ISBN 5-7333-0468-5

7. L. Wittgenstein. Tractatus logico-philosophicus. Side-by-side-by-side edition, version 0.58 (2020) http://people.umass.edu/klement/tlp/ (Accessed 15 June 2020).

8. A. Loreti. Tema molchaniya $v$ filosofii L. Vitgenshteyna [The theme of silence in Wittgenstein's philosophy]. Vestnik RKhGA [Bulletin of the Russian Christian Humanitarian Academy] № 1 (2016). https://cyberleninka.ru/article/n/tema-molchaniya-v-filosofii-l-vitgenshteyna (Accessed 27 December 2018).

9. M.S. Kagan. Mir obshcheniya: Problema mezhsubyektnykh otnosheniy [The world of communication: the problem of intersubject relations]. Politizdat, Moscow (1988). ISBN 5-250-00034-7

10. Yu. M. Lotman. Zamechaniya o strukture povestvovatelnogo teksta [Notes on the structure of the narrative text], Uchenyye zapiski Tartuskogo gosudarstvennogo universiteta. Vypusk 308. Trudy po znakovym sistemam. T. VI. [Notes of the Tartu State University. Issue 308. Articles on the sign systems. Volume VI]. Tartu (1973).

11. M. Sh. Bonfeld. Muzyka: yazyk ili rech? [Music: language or speech?] Muzykalnaya kommunikatsiya: sbornik nauch. trudov. [Musical communication: collection of studies]. SPb. 1996. http://opentextnn.ru/music/Perception/?id=1416 (Accessed 15 June 2020).

12. V. Martynov. Konets vremeni kompozitorov [End of composers ' Era]. Russkiy put, Moscow (2002). www.rp-net.ru (Accessed 15 June 2020). ISBN 5858871437 
13. B. V. Asafyev. Muzykalnaya forma kak protsess [Musical form as a process]. Muzyka, Leningrad (1971).

14. N.P. Shishlyannikova. Muzyka kak yazyk neverbalnoy mezhkulturnoy kommunikatsii [Music as a language of non-verbal cross-cultural communication]. Mir yazykov: rakurs i perspektiva : materialy IV Mezhdunarodnoy nauchnoy prakticheskoy konferentsii [The world of languages: perspective and perspective: materials of the IV International scientific practical conference. Minsk. April 22, 2013]. Minsk. 22 aprelya 2013 g. BGU, Minsk (2013). ISBN 978-985-500-484-5

15. M. Yu. Gudova. Intonatsiya: dukhovnyye istoki i khudozhestvennyye smysly [Intonation: spiritual origins and artistic meanings]. AMB, Ekaterinburg (2004). ISBN 5-8057-0361-0

16. V.I. Martynov. 3ona opus posth. ili Rozhdeniye novoy realnosti [Opus posth zone, or the birth of a new reality]. Izdatelskiy dom "Klassika-XXI", Moscow (2005). ISBN 5-89817-119-3.

17. V.V. Bibihin Yazyk filosofii [The language of philosophy]. Yazyki slavyanskoj kul'tury, Moscow (2002). ISBN 5-94457-042-3

18. T. V. Katyukhina. "Chelovek molchashchiy" kak predmet issledovaniya filosofskoy antropologii ["The silent man" as a subject of research in philosophical anthropology]. Vestnik RUDN. Seriya: Filosofiya. [RUDN Bulletin. Series: Philosophy] N.4 (2009). pp. 86-92. ISSN: 2313-2302

19. T. B. Sidneva. Shum i muzyka: logika vzaimoprevrashcheniy [Noise and music: the logic of mutual conversions]. Izvestiya ross. gos. ped. un-ta im. A. I. Gertsena [Bulletin of the Russian State Pedagogical University named after A. I. Herzen] № 146 (2012). pp. 25-33. ISSN: 1992-6464

20. V. Mikhaylov. Muzyka $\mathrm{v}$ istorii kultury [Music in the history of culture]. MGK, Moscow (1998). ISBN 5-89598-011-2

21. I. Nekrasova. "Paralleli" zvuka: shum i tishina v khudozhestvennom prostranstve XX veka ["Parallels" of sound: noise and silence in the art space of the XX century]. Traditsii i perspektivy iskusstva kak fenomena kultury: sb. nauch. tr. Gosudarstvennaya klassicheskaya akademiya im. Maymonida. [Traditions and perspectives art as a phenomenon of Russian culture: collection of studies], Gosudarstvennaya klassicheskaya akademiya im. Maymonida [Sate Classical Academy named after Maimonid]. Moscow (2016). pp. 187-193. 